\title{
Atmospheric boundary layer top height in South Africa: measurements with lidar and radiosonde compared to three atmospheric models
}

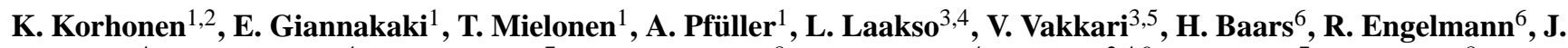 \\ P. Beukes ${ }^{4}$, P. G. Van Zyl ${ }^{4}$, A. Ramandh ${ }^{7}$, L. Ntsangwane ${ }^{8}$, M. Josipovic ${ }^{4}$, P. Tiitta ${ }^{2,4,9}$, G. Fourie ${ }^{7}$, I. Ngwana ${ }^{8}$, \\ K. Chiloane ${ }^{10}$, and M. Komppula ${ }^{1}$ \\ ${ }^{1}$ Finnish Meteorological Institute, P.O. Box 1627, 70211, Kuopio, Finland \\ ${ }^{2}$ Department of Applied Physics, University of Eastern Finland, P.O. Box 1627, 70211 Kuopio, Finland \\ ${ }^{3}$ Finnish Meteorological Institute, P.O. Box 503, 00101, Helsinki, Finland \\ ${ }^{4}$ Unit for Environmental Sciences and Management, North-West University, Potchefstroom, South Africa \\ ${ }^{5}$ Department of Physics, University of Helsinki, P.O. Box 64, 00014 Helsinki, Finland \\ ${ }^{6}$ Leibniz Institute for Tropospheric Research, Permoserstrasse 15, 04318, Leipzig, Germany \\ ${ }^{7}$ Sasol Technology R\&D (Pty) Ltd., P.O. Box 1, Sasolburg, South Africa \\ ${ }^{8}$ South African Weather Service, Pretoria, South Africa \\ ${ }^{9}$ Department of Environmental Sciences, University of Eastern Finland, P.O. Box 1627, 70211 Kuopio, Finland \\ ${ }^{10}$ Eskom Holdings SOC Ltd; Sustainability Division; Research, Testing and Development, South Africa
}

Correspondence to: M. Komppula (mika.komppula@fmi.fi)

Received: 16 April 2013 - Published in Atmos. Chem. Phys. Discuss.: 1 July 2013

Revised: 15 March 2014 - Accepted: 17 March 2014 - Published: 30 April 2014

\begin{abstract}
Atmospheric lidar measurements were carried out at Elandsfontein measurement station, on the eastern Highveld approximately $150 \mathrm{~km}$ east of Johannesburg in South Africa throughout 2010. The height of the planetary boundary layer (PBL) top was continuously measured using a Raman lidar, Polly XT (POrtabLe Lidar sYstem eXTended). High atmospheric variability together with a large surface temperature range and significant seasonal changes in precipitation were observed, which had an impact on the vertical mixing of particulate matter, and hence, on the PBL evolution. The results were compared to radiosondes, CALIOP (Cloud-Aerosol Lidar with Orthogonal Polarization) spaceborne lidar measurements and three atmospheric models that followed different approaches to determine the PBL top height. These models included two weather forecast models operated by ECMWF (European Centre for Mediumrange Weather Forecasts) and SAWS (South African Weather Service), and one mesoscale prognostic meteorological and air pollution regulatory model TAPM (The Air Pollution Model). The ground-based lidar used in this study was oper-
\end{abstract}

ational for $4935 \mathrm{~h}$ during 2010 (49\% of the time). The PBL top height was detected $86 \%$ of the total measurement time (42\% of the total time). Large seasonal and diurnal variations were observed between the different methods utilised. High variation was found when lidar measurements were compared to radiosonde measurements. This could be partially due to the distance between the lidar measurements and the radiosondes, which were $120 \mathrm{~km}$ apart. Comparison of lidar measurements to the models indicated that the ECMWF model agreed the best with mean relative difference of $15.4 \%$, while the second best correlation was with the SAWS model with corresponding difference of $20.1 \%$. TAPM was found to have a tendency to underestimate the PBL top height. The wind speeds in the SAWS and TAPM models were strongly underestimated which probably led to underestimation of the vertical wind and turbulence and thus underestimation of the PBL top height. Comparison between ground-based and satellite lidar shows good agreement with a correlation coefficient of 0.88 . On average, the daily maximum PBL top height in October (spring) and June (winter) 
was $2260 \mathrm{~m}$ and $1480 \mathrm{~m}$, respectively. To our knowledge, this study is the first long-term study of PBL top heights and PBL growth rates in South Africa.

\section{Introduction}

The planetary boundary layer (PBL), being the lowest part of the atmosphere, is strongly affected by the Earth's surface at all times of the day. Daily PBL development is conditioned by several parameters such as local thermal and dynamic forcings, as well as by forcing on a synoptic scale. The variance in local forcings (e.g. surface temperature) causes spatial and temporal alteration in PBL dynamics. For instance, ground-based emissions of particulate matter are mixed and distributed mainly inside the PBL.

Seibert et al. (2000) published a comprehensive study on the comparison of different operative measurement methods for PBL top height, where the importance of choosing between acknowledged definitions of PBL is emphasised. We adopted the definition used by Stull (1988), according to which the PBL top is defined as the lowest part of the troposphere that is directly influenced by the earth's surface, which responds to surface forcings within one hour or less.

There are many methods for determining the PBL height from vertically resolved measurements. Globally, measurement with radiosondes is a widely applied operational method (Seibert et al., 2000). Quality-controlled radiosonde data has been available for decades, which makes the method suitable for long-term climatological studies on many continents (Seidel et al., 2012). There have been numerous studies on the determination of the PBL height from radiosonde measurement data (e.g. Johansson and Bergström, 2005) and it is known that the interpretation is not always straightforward due to technical limitations (van Pul et al., 1994), such as altering vertical resolution due to horizontal movement along wind fields during the ascent of the instrument.

PBL top height is a crucial component in air pollution models because it determines the vertical space and consequently the volume for pollutant mixing, which is a key parameter for assessment of concentrations. Turbulence in air flow due to surface friction also affects the horizontal distribution of pollutants and is an important factor in weather forecast models. The PBL height cannot be directly measured by standard meteorological observations but it is a quantity that can be derived from the observations. The different parametrisations of models affect the precision of the simulated PBL height and therefore validation with measurements is essential (e.g. Hurley et al., 2008).

Lidar (light detection and ranging) systems provide continuous measurement of numerous atmospheric quantities, including the vertical profile of atmospheric aerosols from which the PBL height can be derived (Matthias et al., 2004; Amiridis et al., 2007; Baars et al., 2008; Groß et al., 2011;
Tsaknakis et al., 2011; Haeffelin et al., 2012; Cimini et al., 2013). Aerosols and pollutants are vertically mixed inside the PBL during daytime when mixing is driven by convection and turbulence in air flow. The PBL top height is indicated by a gradient in the vertical backscatter coefficient profile derived from the lidar measurement signal.

PBL top height determination is also possible using data from an active space-borne lidar, which possesses the ability to view vast and remote areas on a regular basis. Attenuated backscatter profiles derived from the measurements of the CALIOP (Cloud-Aerosol Lidar with Orthogonal Polarization) on board the CALIPSO (Cloud-Aerosol Lidar and Infrared Pathfinder Satellite Observations, Winker et al., 2004, 2006 , 2007) satellite can be used to study the vertical structure of aerosols, and hence, to define the PBL top height (Jordan et al., 2010). However, operational CALIOP PBL product is currently not available.

Previous studies have indicated that South Africa is one of the most affected countries with regard to aerosol load, due to various natural and anthropogenic activities (Piketh et al., 1999, 2002; Formenti et al., 2002, 2003; Liu, 2005; Queface et al., 2011). In addition to information already derived from the above-mentioned studies, lidar studies can give detailed information on the vertical stratification, optical and microphysical properties of aerosols. A detailed characterisation of aerosol properties, vertical stratification, mixing, and aging behaviour of aerosols in West Africa has been performed based on a unique data set of spectrally resolved backscatter and extinction coefficients and the depolarisation ratio (Ansmann et al., 2009, 2011). The authors studied the complex layer structure of Sahara dust and biomass burning aerosols observed at Praia, Cape Verde and how the African plume reached the South American coast. Campbell et al. (2003) have found lidar ratios between 50 and $90 \mathrm{sr}$, with the Ångström exponent of 1.5-2, for dense biomass smoke events during the South African Regional Science Initiative (SAFARI) 2000 (Swap et al., 2003). The lidar ratio (Ansmann et al., 1992) and Ångström exponent (Ångström, 1929) refer to the extinction-to-backscatter ratio and wavelength dependency of aerosol extinction or backscatter coefficient, respectively. They studied backscatter profiles from a micropulse lidar system and compared the results to Sun photometer aerosol optical depth measurements. As these examples indicate, lidar studies in South Africa have mostly been limited to specific case studies.

In this study we conducted continuous long-term groundbased lidar measurements at Elandsfontein, South Africa, throughout the year 2010 in the framework of the EUCAARI (European Integrated Project on Aerosol Cloud Climate and Air Quality Interactions) project (Kulmala et al., 2011). This is a relatively polluted region where the number of previous atmospheric measurement campaigns has been limited. We compared one year of PBL top height data retrieved from a ground-based lidar measurements with radiosondes, three atmospheric models and space-borne lidar retrievals. The aim 

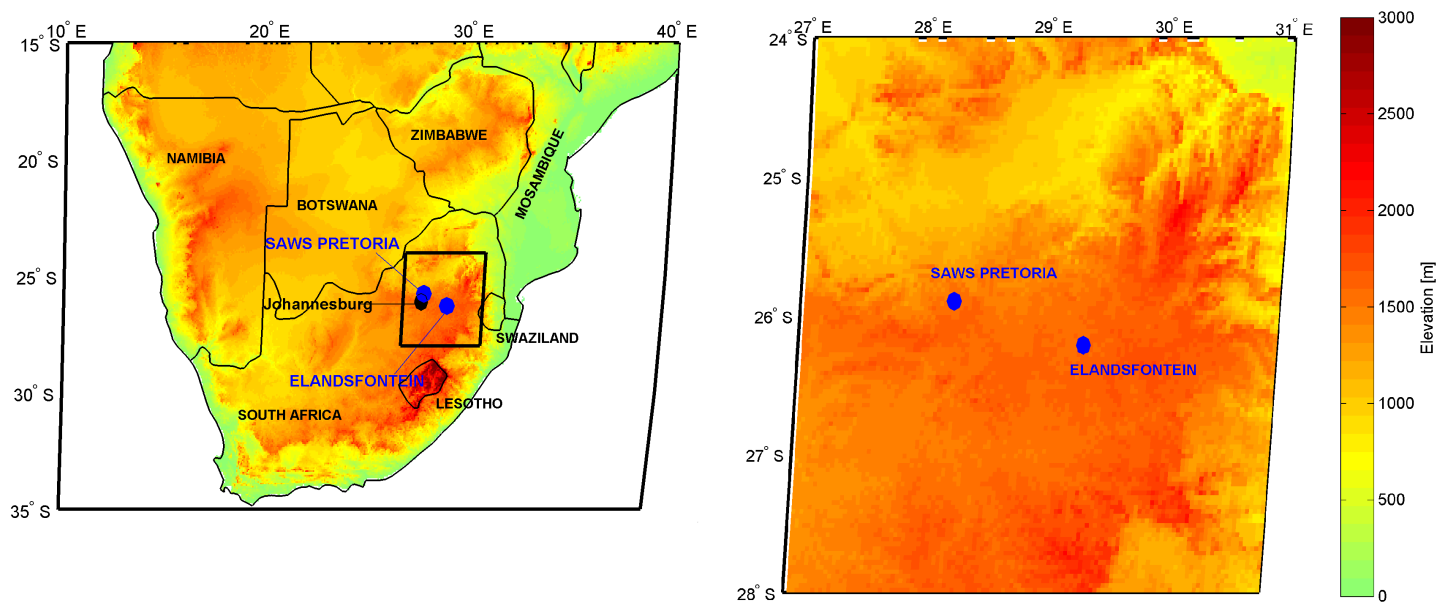

Fig. 1. Location of measurement site and the orographic information of the surroundings. The Elandsfontein lidar site was located $150 \mathrm{~km}$ east from Johannesburg. The map shows the location of the Pretoria sounding station $120 \mathrm{~km}$ from the lidar site.

of this study was to provide information on PBL characteristics in South Africa, and to compare the measured PBL top heights to ones simulated by different atmospheric models. This study is the first long-term study of PBL top heights and PBL growth rates in South Africa.

\section{The measurement site}

The lidar measurement site was located on a hill top at Elandsfontein $\left(26^{\circ} 15^{\prime} \mathrm{S}, 29^{\circ} 26^{\prime} \mathrm{E}, 1745 \mathrm{~m}\right.$ a.s.l, which is situated in the eastern part of the Highveld region (Fig. 1) in South Africa. The Highveld is a large plateau that covers $400000 \mathrm{~km}^{2}$, with an average mean altitude of $1500 \mathrm{~m}$ a.s.l, varying from 1400 up to $1800 \mathrm{~m}$ a.s.l. (Fig. 1). The local time zone is UTC +2 and it has been used in the presentation of all data. The station is located about $150 \mathrm{~km}$ east from the Johannesburg-Pretoria megacity, the largest metropoli$\tan$ area in South Africa with a population of over 10 million people (Lourens et al., 2012). The surroundings close to the Elandsfontein site are mostly rural with agriculture activities, while the larger region includes mining and industrial activities. Laakso et al. (2012) gave a detailed description of the measurement site.

The main anthropogenic emission sources in this area include high-capacity power production with coal-fired power plants (Lourens et al., 2011), yielding nearly half of all electricity produced on the African continent. In addition, there are many other industrial sources of nitrogen and sulfuric oxides, such as petrochemical industry and mining activities. The area surrounding the measurement site is globally regarded as one of the top five hotspots of nitrogen oxide emissions (Lourens et al., 2011, 2012). Other anthropogenic emissions in this area include household combustion (for space heating and cooking) and controlled, as well as uncontrolled burning of vegetation. Wildfires and controlled burn- ing of vegetation are significant sources of particulate emissions, especially during May-September. During the measurement campaign the fire frequency in the surroundings of Elandsfontein was highest in September (the end of the dry season), and lowest in March (the end of the wet season) (http://earthdata.nasa.gov/data/near-real-time-data/firms).

A dominant characteristic of the South African Highveld climate is the variation between wet (October-March) and dry seasons (April-September). Approximately $90 \%$ of the annual precipitation falls during the wet season. The limited cloud cover during the dry season results in strong nocturnal inversions and reduced vertical mixing at night-time (Laakso et al., 2012), while during daytime strong surface heating and thus vertical mixing occurs. In contrast, the cloudiness and precipitation increase dramatically during the rainy season. This affects the characteristics of PBL in two ways. First, cloudiness affects the solar radiation reaching the earth's surface and thus weakens convective mixing. Secondly, wet soil and vegetation of grassland and agricultural land (due to intensive rainfall) have a greater heat capacity than dry soil and vegetation, which reduce the adiabatic heating of air by the surface and thus weakens the convective mixing during the rainy season.

Meteorological quantities at Elandsfontein were measured with a Vaisala WXT510 meteorological station. Figure 2a shows the annual cycle of temperature during 2010. The hottest month was February, while July was the coldest month with average temperatures of $18.5^{\circ} \mathrm{C}$ and $9.4^{\circ} \mathrm{C}$, respectively. The annual average temperature was $15.4^{\circ} \mathrm{C}$. The temperature cycle in 2010 agreed well with long-term climate statistics (World Meteorological Organization, http: //www.worldweather.org/035/c00139.htm). The annual average temperature measured for 2010 was $0.5^{\circ} \mathrm{C}$ lower than the annual average temperature observed between 1961 and 1990. Figure $2 \mathrm{~b}$ shows the monthly averages of daily 

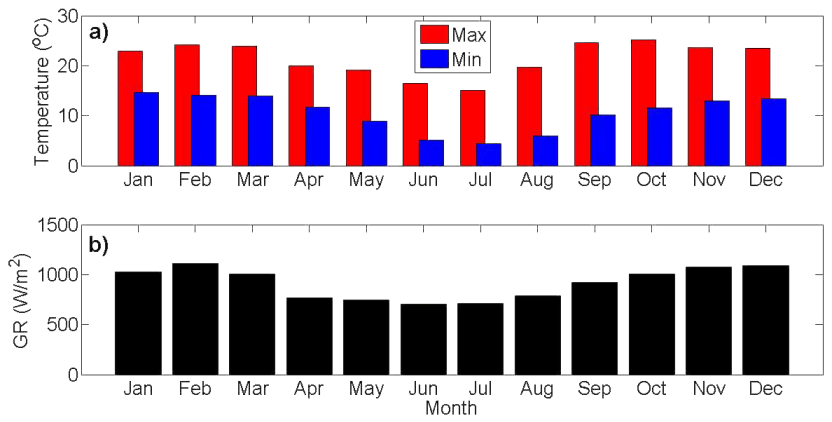

Fig. 2. Measured average temperatures (a) and daily maximum global radiation intensity (b) at Elandsfontein during 2010. In (a) the red bars indicate daily average maximum and blue bars the daily average minimum temperature. The values were calculated from $15 \mathrm{~min}$ averages.

maximum global radiation intensities measured on site using a Kipp and Zonen CMP21 pyranometer. The seasonal cycle shows that the highest daily intensities were measured in February $\left(1114 \mathrm{Wm}^{-2}\right)$, which was also the hottest month. Lowest maximum intensities were observed in the coldest months, i.e. June and July, when $706 \mathrm{Wm}^{-2}$ and $713 \mathrm{Wm}^{-2}$ was measured, respectively.

\section{Methods}

\subsection{Radiosonde}

The data acquired from radiosonde measurement typically consist of vertical profiles of temperature, pressure, relative humidity, wind speed and wind direction. By using this obtained meteorological data the PBL height can be derived. For this study, we used radiosonde data measured in Pretoria $\left(25^{\circ} 33^{\prime} \mathrm{S}, 28^{\circ} 8^{\prime} \mathrm{E}, 1523 \mathrm{~m}\right.$ a.s. 1.$), 120 \mathrm{~km}$ northwest from the lidar site. This site is the closest site where such measurements are conducted on a regular basis. The sounding site is being operated by the South African Weather Service (SAWS) and the sondes are launched twice a day at fixed times, i.e. 10:00 and 22:00. Other relevant parameters are presented in Table 1. Radiosonde measurements were obtained for 409 soundings on 200 separate days during 2010. Soundings were not available for the periods 16 June- -12 July and 3 August-17 October 2010.

For PBL height determination we used the bulk Richardson number (BRN) method (Troen and Mahrt, 1986) as follows. Potential temperature profile was calculated for each sounding according to Stull (2000):

$\theta=T\left(\frac{P_{0}}{P}\right)^{\frac{\rho}{C_{\mathrm{P}}}}$

where $T$ is temperature in Kelvin, $P$ pressure, $P_{0}$ reference pressure $\left(P_{0}=850 \mathrm{hPa}\right), \rho$ dry adiabatic lapse rate and $C_{\mathrm{p}}$ the heat capacity for dry air that resulted in the exponent $\rho C_{\mathrm{p}}^{-1}=0.28571$. Then, using the potential temperature and wind profile, the vertical BRN profile was determined using the formula introduced by Menut et al. (1999):

$R i_{\mathrm{b}}(h)=\frac{g\left(h-h_{0}\right)}{\theta(h)} \frac{\left[\theta(h)-\theta\left(h_{0}\right)\right]}{u(h)^{2}+v(h)^{2}}$

where $h$ is altitude, $h_{0}$ the altitude of ground, $g$ gravitational acceleration $\theta$ the potential temperature in Kelvin and $u$ and $v$ the zonal and meridional wind components, respectively. The critical value $R i_{\text {Cr }}$ was set to 0.25 , which is also used in the ECMWF model. We used linear interpolation with 10metre interval in order to have the profiles on a standard grid. The PBL height was determined to be the lowest altitude where $\mathrm{BRN}$ reaches the critical value.

\subsection{Polly ${ }^{\mathrm{XT}}$ lidar instrument}

The ground-based lidar used in this study is the sevenchannel Raman lidar, Polly ${ }^{X T}$ (POrtabLe Lidar sYstem eXTended, Althausen et al., 2009), designed for continuous measurements of vertical profiles of both particle and molecular backscatter and extinction. The instrument is entirely remotely controlled via an internet connection, and measurements, data transfer and built-in device regulation are performed automatically. Weekly maintenance visits to the site were carried out to ensure the quality of the measurements.

The Polly ${ }^{\mathrm{XT}}$ lidar uses a Continuum Inlite III type laser. The pulse rate of the laser is $20 \mathrm{~Hz}$ and it delivers energies of $180 \mathrm{~mJ}, 110 \mathrm{~mJ}$ and $60 \mathrm{~mJ}$ simultaneously at three different wavelengths, i.e. $1064 \mathrm{~nm}, 532 \mathrm{~nm}$ and $355 \mathrm{~nm}$, respectively. The vertical resolution of the system is $30 \mathrm{~m}$ and the vertical range covers the whole troposphere under cloudless conditions. A detailed description of the Polly ${ }^{\mathrm{XT}}$ lidar system can be found in Althausen et al. (2009).

During the measurement period, vertical profiles of particle backscatter coefficients at 355, 532 and $1064 \mathrm{~nm}$, extinction coefficient at 355 and $532 \mathrm{~nm}$ and the linear particle depolarisation ratio at $355 \mathrm{~nm}$ were obtained from the instrument. The measurement of the height and diurnal evolution of the PBL top was based on the analysis of aerosol layers, derived from vertical backscattering profiles at the wavelength of $1064 \mathrm{~nm}$. Table 1 presents the relevant properties of Polly ${ }^{\mathrm{XT}}$ used in this study, together with the properties of the other techniques utilised. The other techniques will be discussed in subsequent paragraphs.

The Polly XT measurements started on 27 January 2010, lasting until 31 December 2010 with a total instrument running time of $4935 \mathrm{~h}$. The days when lidar measurements were performed were used as the basis for the comparison between different methods discussed in this paper. Figure 3 shows the lidar data coverage for each month during 2010 . The overall data coverage was $49 \%$. If the maintenance breaks (1-26 January and 23 October-23 November) are excluded the data coverage increases to $60 \%$. The dark blue bar shows the percentage of PBL observations. The monthly amount of PBL 
Table 1. The main properties of the methods used in this study.

\begin{tabular}{|c|c|c|c|c|c|}
\hline Method & Temporal resolution & Vertical resolution and range & Horizontal grid resolution & PBL types included & $\begin{array}{l}\text { PBL height determination } \\
\text { method }\end{array}$ \\
\hline Polly XT & 15 min (adjustable) & $30 \mathrm{~m}(0-25 \mathrm{~km}$ or more $)$ & point measurement & $\mathrm{CBL}+\mathrm{RL}$ & $\begin{array}{l}\text { Maximum mixing height } \\
\text { via aerosol layer top height }\end{array}$ \\
\hline Radiosonde & $12 \mathrm{~h}$ & $\min .50 \mathrm{~m}$ (up to ca. $20 \mathrm{~km}$ ) & point measurement & $\mathrm{CBL}+\mathrm{RL}$ & $\begin{array}{l}\text { Bulk Richardson number } \\
\left(R i_{\mathrm{Cr}}=0.25\right)\end{array}$ \\
\hline ECMWF & $3 \mathrm{~h}$ & 62 levels (highest level $5 \mathrm{hPa}$, & $0.2^{\circ}(\sim 20 \mathrm{~km})$ & $\mathrm{CBL}+\mathrm{SBL}$ & $\begin{array}{l}\text { Bulk Richardson number } \\
\left(R i_{\mathrm{Cr}}=0.25\right)\end{array}$ \\
\hline SAWS (Unified Model, & $1 \mathrm{~h}$ & $\begin{array}{l}\text { typ. at ca. } 45 \mathrm{~km}) \\
16 \text { levels }(850-100 \mathrm{hPa} \text {, }\end{array}$ & $12 \mathrm{~km}$ & $\mathrm{CBL}+\mathrm{RL}$ & $\begin{array}{l}\text { Bulk Richardson number } \\
\left(R i_{\mathrm{Cr}}=0.25\right)\end{array}$ \\
\hline South African domain archive) & & typ. at ca. $16 \mathrm{~km}$ ) & & & \\
\hline TAPM & $1 \mathrm{~h}$ & 44 levels $(0-4 \mathrm{~km}$, adjustable $)$ & $1 \mathrm{~km}$ (adjustable) & $\mathrm{CBL}+\mathrm{SBL}$ & Convective updraft strength \\
\hline CALIOP & 16-day repeat cycle & $30 \mathrm{~m}$ & $5 \mathrm{~km}$ & $\mathrm{CBL}+\mathrm{RL}$ & $\begin{array}{l}\text { Feature Detection and } \\
\text { Layer Properties Algorithm }\end{array}$ \\
\hline
\end{tabular}

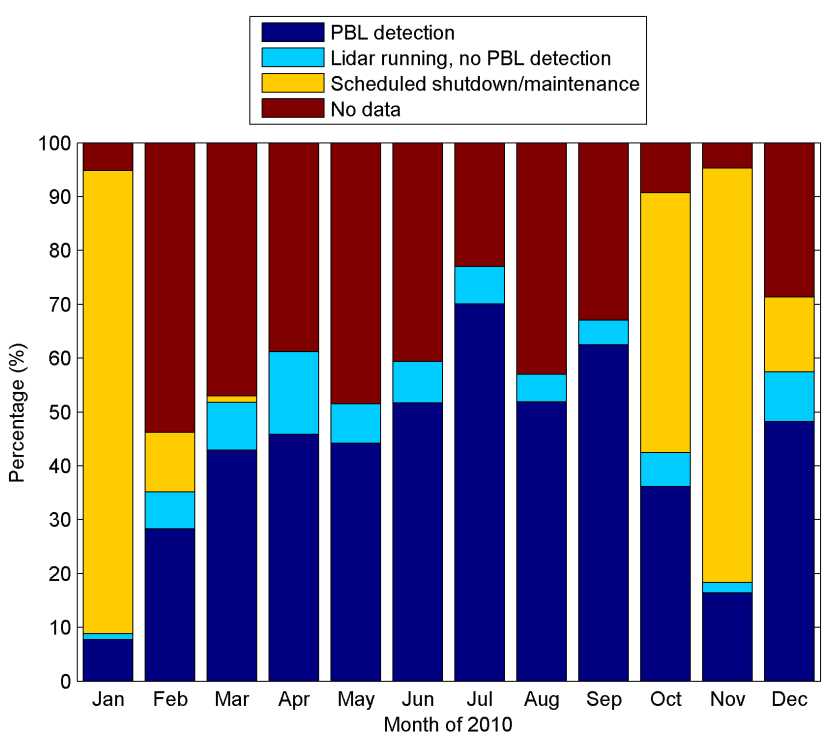

Fig. 3. Data coverage of lidar measurement during 2010 categorised into different classes.

detection varied from $60 \mathrm{~h}$ in January to $520 \mathrm{~h}$ in July (8$70 \%)$. For the measurement time of the lidar the PBL could be detected on an average of $86 \%$ of the data. Failures in the PBL height determination were attributed to low clouds (including fog) and thick aerosol plumes, which occasionally caused the detection of complex aerosol layer structures. The latter was caused by strong aerosol sources (e.g. originating from power plants, wildfires) in the proximity of the lidar site. The best data coverage was achieved between June and September, when the best PBL detection rate of $93 \%$ was achieved (September) due to favourable weather conditions. Between June and September only $3.6 \%$ (69.5 h) of the measurement time had clouds. In Fig. 3 the yellow bars indicate the maintenance breaks, as well as the scheduled midday breaks to protect the optics from high sun angles in OctoberMarch. The red bars (no data) include electrical breaks, rain and other unwanted breaks in the measurements, as well as bad data.

The PBL top heights were retrieved from the 15 min averaged lidar backscatter signals at $1064 \mathrm{~nm}$ using the Wavelet Covariance Transform (WCT) method (Brooks, 2003). We chose this method because it allows larger adjustability and thus more robust analysis of the PBL height than e.g. the gradient method. The latter is known to be sensitive for any local minima in the backscattering signal (Hennemuth and Lammert, 2006), which causes uncertainty especially during convective situations with turbulent aerosol mixing. The covariance transform is a measure of the similarity of the rangecorrected lidar signal and the related Haar function. The method was applied for the profiles measured with Polly ${ }^{\mathrm{XT}}$ following the guidelines introduced by Baars et al. (2008). The full overlap of the system is calculated to be at $800 \mathrm{~m}$. Nevertheless, PBL detection can be made reliably down to $200-300 \mathrm{~m}$, because the increasing overlap with height causes an increasing signal with height, while the PBL detection algorithm is looking for strong decreases of the lidar signal with height. Thus the detection of the convective PBL is not disturbed, since the convective boundary layer (CBL) is usually higher than $300 \mathrm{~m}$. Based on our data set this caused no issues in the analysis.

The PBL height values obtained from the lidar data were used as the basis throughout the entire comparison period. The hourly PBL top height values were calculated from the lidar data by averaging of the three closest data points of the time considered (e.g. for 12:00 UTC +2 the PBL height would be the average of the three points between 11:45 and 12:15).

The daily PBL growth rates and growth periods were determined as described by Baars et al. (2008), i.e. the main growth period starts when the PBL height begins to increase (typically between 08:00 and 10:00 at the lidar site) and it ends when $90 \%$ of the daily maximum height has been reached (typically between 14:00 and 16:00). The growth rate was then taken to be the slope of a linear fit to the data.

It is worth mentioning that the models considered in this paper and the lidars (surface and space-borne) are able to 
detect the CBL top during daytime, but during night-time the lidars detect the residual layer (RL) top and the models detect the top of the night-time stable boundary layer (SBL). Therefore, only the CBL values were considered in the analysis.

\subsection{The ECMWF model}

The ECMWF runs a global weather forecast model as part of an integrated forecast system. The model version used in this study became operational on 26 January 2010. The model includes a global grid with 0.2 degree horizontal resolution and 62 vertical pressure levels from ground up to $5 \mathrm{hPa}$. Table 1 presents the model properties relevant for this study (ECMWF, 2010a, b). The total time of each model run is $240 \mathrm{~h}$, while the temporal resolution is three hours for the first $72 \mathrm{~h}$ and six hours after this initial period. In this study, the only model parameter used was the PBL top height. ECMWF (2010b) presents a detailed description of all the parameters relevant to PBL dynamics that are used in the simulation. We chose the four closest grid points surrounding the Elandsfontein lidar site, at distances of 24.5, 16.8, 18.8 and $5.9 \mathrm{~km}$ and with an orientation of south-east, south-southwest, northeast and north-northwest from the lidar site, respectively. The PBL height for the lidar site was interpolated using distanceweighted averages of these four data points. A more detailed description of the model is given in ECMWF (2010c).

The ECMWF model defines the PBL top height by using the BRN method with $R i_{\mathrm{Cr}}$ value of 0.25 (ECMWF, 2010b). If the $R i_{\mathrm{Cr}}$ is detected between two vertical levels, linear interpolation is used for finding the PBL top height. This method combined with 62 vertical grid levels ensures high accuracy in modelling. The model gives the height of the SBL in non-convective conditions and due to this characteristic we analysed only daytime (08:00, 11:00, 14:00 and 17:00) values. The non-convective values were left out of the comparison with the lidar measurements. The PBL growth rates were determined from the slope of the linear fit to PBL heights between the first data point after sunrise (08:00) and the point when the model indicated the daily maximum height (mostly at 17:00).

\subsection{The SAWS operated model}

The SAWS operates a regional Unified Model for local weather forecasts. It is run at $12 \mathrm{~km}$ horizontal resolution with 38 vertical levels to produce $48 \mathrm{~h}$ forecast, with and without data assimilation (Landman et al., 2012). Temporal resolution of the output ranges from minutes to hours. However, in this study we used the archived South Africa domain data which has 16 vertical levels at our site with a $1 \mathrm{~h}$ resolution. The 16 model levels cover pressure levels from $850 \mathrm{hPa}$ to $100 \mathrm{hPa}$ with an interval of $50 \mathrm{hPa}$. Under typical South African climatic conditions the vertical grid extends from the ground level up to approximately $16 \mathrm{~km}$ above ground level. The horizontal grid of the SAWS model was centred at Elandsfontein in this study and the studied PBL parameters were vertical profiles of temperature, pressure and wind, from which the PBL top height was derived with the BRN method, i.e. the same as was used for the radiosondes. The PBL growth rate was determined from the slope of the linear fit between the time at which the PBL top height started to increase and the daily maximum height. The relevant properties of the SAWS model are summarised in Table 1.

The SAWS model data covered the whole year and the PBL heights were calculated for the days when Polly XT was operational, i.e. $24 \mathrm{PBL}$ top height values for each day. The ECMWF model (Section 3.3) and the TAPM model (Sect. 3.5) produced 8 and 24 PBL top height values per day, respectively.

\subsection{TAPM}

The Air Pollution Model (TAPM), developed by the Australian CSIRO Atmospheric Research Division, is the third model chosen for this study. It is an integrated 3-D mesoscale prognostic meteorological and air pollution regulatory model (Hurley et al., 2005a, b; Luhar and Hurley, 2004; Raghunandan et al., 2008). The meteorological component of TAPM is an incompressible, optionally non-hydrostatic, primitive equation model which uses a terrain-following vertical coordinate system for 3-D simulations (Zawar-Reza and Sturman, 2008). It includes comprehensive parametrisations for cloud/rain micro-physical processes, urban/vegetative canopy and soil, as well as turbulence closure and radiative fluxes (Lai and Chang, 2009). TAPM predicts local-scale flows, such as sea breezes and terrain-induced circulations, by utilising meteorological fields obtained from larger-scale synoptic analyses (Luhar and Hurley, 2004).

Properties of TAPM are presented in Table 1. The model grid was centred to the lidar site and the synoptic scale analyses data and Limited Area Prediction System (LAPS) or Global Analysis and Prediction (GASP) analysis data, was obtained from the Australian Bureau of Meteorology. The vertical grid of TAPM is adjustable and the uppermost level height used in the model run was $4 \mathrm{~km}$. The PBL parameters studied were, in addition to the PBL top height, temperature, wind and solar radiation intensity.

The TAPM model defines the PBL height through the strength of convective updraft. During daytime, the PBL top is reached at the first vertical level where convective updraft decreases to zero and during night-time when the vertical heat flux has decreased to $5 \%$ or less from the surface value (Hurley, 2008). In other words, the TAPM detects the PBL height via investigating the influence of Earth's surface to heat flux; during the day this effect is transfer of convective heat energy from solar radiation (CBL) and during night, transfer of heat which has been capacitated to soil during day (SBL). Similar to the ECMWF model, TAPM also produces the height of the SBL during night-time. Therefore, the data chosen for comparison with measurements included 

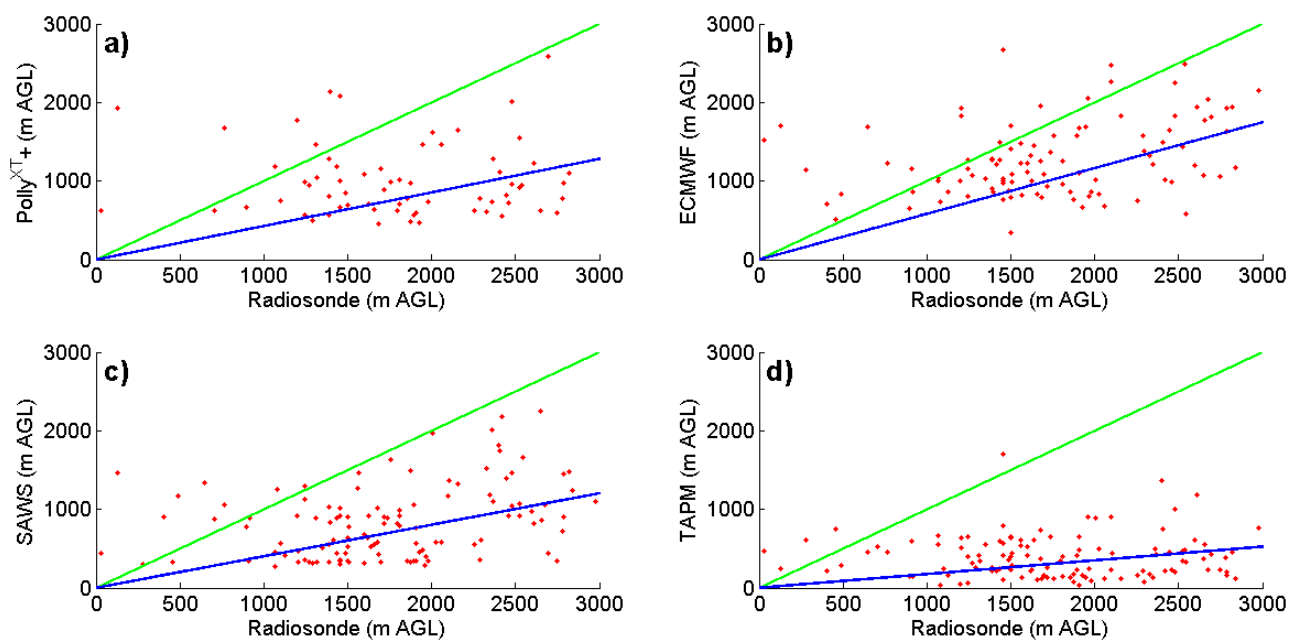

Fig. 4. Scatter plots for comparing Polly ${ }^{X T}$ (a), the ECMWF (b), SAWS (c) and the TAPM model (d) to daytime radiosonde observations in the comparison period. Blue and green lines mark linear fit to the data and 1:1 correlation, respectively.

only daytime values (08:00-17:00). Growth rates were calculated similarly to the SAWS model.

\subsection{Space-borne lidar: CALIOP}

CALIPSO is an Earth Science observation mission launched on 28 April 2006. Onboard CALIPSO is CALIOP, a lidar operating at 532 and $1064 \mathrm{~nm}$ and equipped with a depolarisation channel at $532 \mathrm{~nm}$. There are three basic types of level 2 data products: layer products, profile products and the vertical feature mask. Layer products provide layer-integrated or layer-averaged properties of detected aerosol and cloud layers. Operational CALIOP PBL product is currently not available. The relevant properties of CALIOP are summarised in Table 1.

During 2010, 102 CALIPSO overpasses were available inside a $2 \times 2$ degree box centred on Elandsfontein. The minimum overpass distance was $60 \mathrm{~km}$, while the maximum distance was $110 \mathrm{~km}$ from the lidar station. In 61 cases the boundary top location algorithm (SIBYL, Selective Iterated Boundary Locator) identified at least one layer, while in 41 cases no layers could be identified. For this total of 61 cases, the PBL top from the ground-based lidar was available for 29 cases. In those cases when two or more layers were observed, we considered the top of the first layer from the ground to be the PBL top height. However, in three cases, the top of the second layer was taken, since it was obvious from the attenuated backscatter image provided by CALIOP (http://www.calipso.larc.nasa. gov/products/lidar/browse_images/production/) that the first layer corresponds to a layer inside the PBL.

In order to determine the PBL height from the CALIOP measurements, several methods have been developed using level 1B attenuated backscatter data (e.g. maximum variance technique Jordan et al., 2010). However, level 1B
CALIOP products present low reliability for the altitudes we study, especially during daytime because of the high background solar radiation. The low signal-to-noise ratio of CALIOP profiles complicates the detection of a gradient in aerosol backscatter (Jordan et al., 2010). In this study, we used the level 2 aerosol layer product. The CALIOP layer detection algorithm is described in detail in Vaughan et al. (2005) and in Sect. 5 of the CALIPSO Feature Detection ATBD (http://www-calipso.larc.nasa.gov/resources/ pdfs/PC-SCI-202_Part2_rev1x01.pdf). The CALIOP level 2 aerosol layer product provides information on the base and top heights of existing aerosol layers, reported at a uniform $5 \mathrm{~km}$ horizontal resolution.

\section{Results and discussion}

\subsection{Radiosonde vs. other methods}

The comparison was carried out by calculating correlations between the results from each method and the radiosonde observations. For comparisons we chose only the morning soundings that were carried out in convective conditions (sun above horizon). These comparisons are presented in Fig. 4.

If the $1: 1$ correlation line between the PBL top heights derived from the radiosonde and the Polly ${ }^{\mathrm{XT}}$ is considered in Fig. 4a, it is evident that almost half of the radiosonde PBL top heights were smaller and half were larger than the top heights from Polly XT (56\% smaller and $44 \%$ larger out of all cases). The deviation is large throughout the comparison period (Fig. 4a). About $10 \%$ of the sounding derived PBL top values were within $\pm 20 \%$ and $30 \%$ were within $\pm 50 \%$ of the lidar PBL top values. For the overall comparison of CBL top heights, the slope of the fit is 0.43 ( $x$ intercept forced to zero in all fittings) with a correlation coefficient 


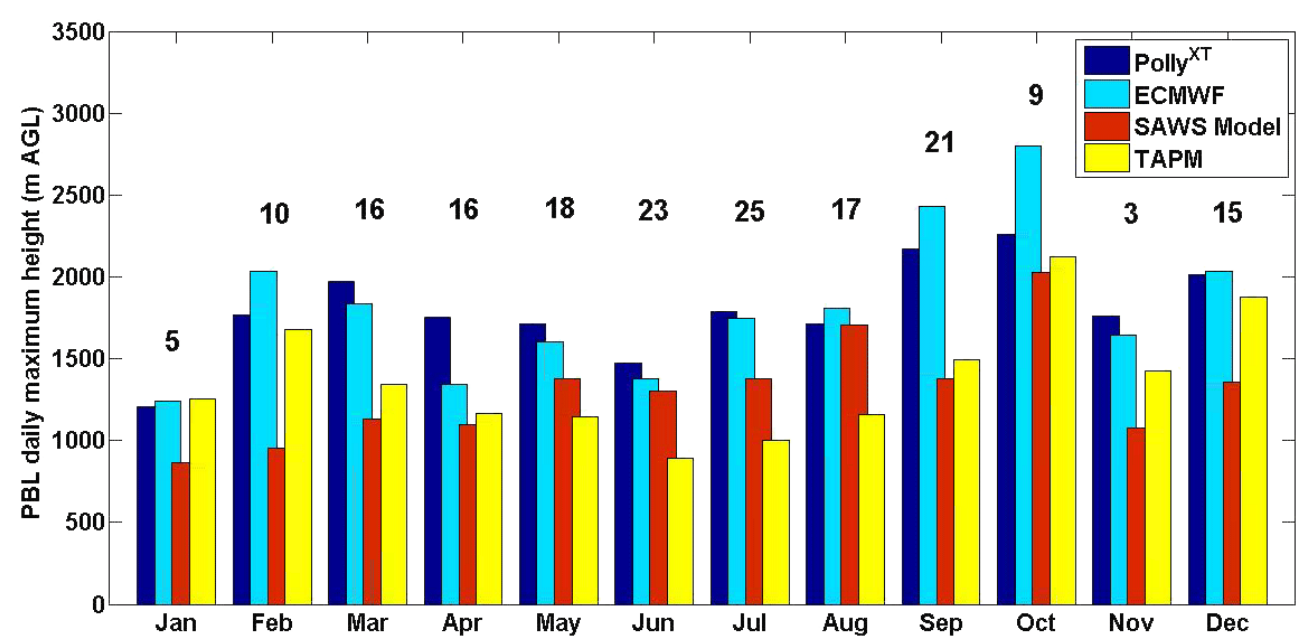

Fig. 5. Monthly averages of PBL daily maximum values. Numbers above bars indicate the number of measurement days on each month.

$(R)$ of 0.05 . The total number of simultaneous observations during daytime is 75 . We carried out a similar comparison for night-time soundings as well and found no significant changes compared to daytime. During night-time (89 soundings), the slope of the fit is close to unity (0.93) and $R$ increases only slightly to 0.06 . In five soundings we found that when completely stable tropospheric conditions persisted, i.e. when the temperature profile follows adiabatic lapse rate, the BRN method suggests the tropopause (ca. $6 \mathrm{~km}$ ) as the PBL top height.

The correlation between the ECMWF model and the radiosondes is presented in Fig. 4b. The fit shows that radiosonde measurements have larger PBL heights with the slope of the linear fit being 0.32 and $R$ being 0.58 . The results show that the soundings give smaller PBL top values in $84 \%$ of the cases and $24 \%$ of the values are within $\pm 20 \%$ and $53 \%$ are within $\pm 50 \%$ of the ECMWF model values. The comparison values for TAPM (slope $/ R$ ) are $0.18 / 0.11$ and for the SAWS model 0.40/0.30 (Fig. 4c, d, respectively).

\subsection{Annual PBL cycle}

The PBL top daily maximum heights were studied for 174 days during 2010. In order to obtain a reliable determination of the daily maximum PBL top height, we required sufficient data coverage between 12:00 and 18:00, i.e. when the maximum height was detected and decrease in PBL top height due to weakening solar radiation was confirmed, with neither wet removal of aerosols (rain) nor clouds inside the convectively mixed aerosol layer. Figure 5 shows the monthly averages of the daily maximum PBL top heights for the studied year. The annual PBL cycle can be clearly seen, i.e. lower daily maximum PBL top heights during the colder dryer months with minimum in June and higher PBL top heights in the hotter weather months with the maxima in October. January and November are somewhat exceptions (Fig. 5), which might be due to the low number of measurement days caused by maintenance breaks. The relatively low average PBL top height value for December can be attributed to increased precipitation and cloudiness ( $205 \mathrm{~h}$, i.e. $48.0 \%$ of the measurement time was cloudy in the Polly ${ }^{\mathrm{XT}}$ data), and therefore less heating from the surface. Overall, the annual cyclic behaviour of PBL top heights follows the cycle of the solar radiation measured at the site (Fig. 2b).

It appears that TAPM produces systematically lower values for PBL top height throughout the year. It has to be noted that the ECMWF modelled results may also underestimate the PBL top maximum height slightly due to the $3 \mathrm{~h}$ data resolution, i.e. the actual PBL maximum values may occur between the data points. Figure 6 shows the frequency distributions of all the daily maxima observed with the Polly XT and the models. As Figures $6 \mathrm{a}$ and $6 \mathrm{~b}$ show, the Polly XT and ECMWF model have a slightly skewed normal distributions with medians of $1730 \mathrm{~m}$ and $1640 \mathrm{~m}$ PBL top height and standard deviations of $565 \mathrm{~m}$ and $620 \mathrm{~m}$, respectively. TAPM (Fig. 6c) also gives a similarly skewed normal distribution, but the median of $1200 \mathrm{~m}$ is approximately $400-500 \mathrm{~m}$ lower. The SAWS model distribution (Fig. 6d) has a median value of $1205 \mathrm{~m}$ which is close to the value obtained from TAPM, but the standard deviation is higher $(810 \mathrm{~m}$ versus $520 \mathrm{~m})$. The interpolation between the model levels improved the result distribution being only slightly skewed normal distribution despite the coarse vertical resolution of the model.

\subsection{Comparison of the PBL top height determination with lidars and models}

The comparison was carried out for boundary layer evolution during convective conditions, i.e. when the sun was above the horizon (11:00-17:00). The modelled PBL top heights were subtracted from those measured with the lidar. Figure $7 \mathrm{a}$ shows the monthly mean difference between each 

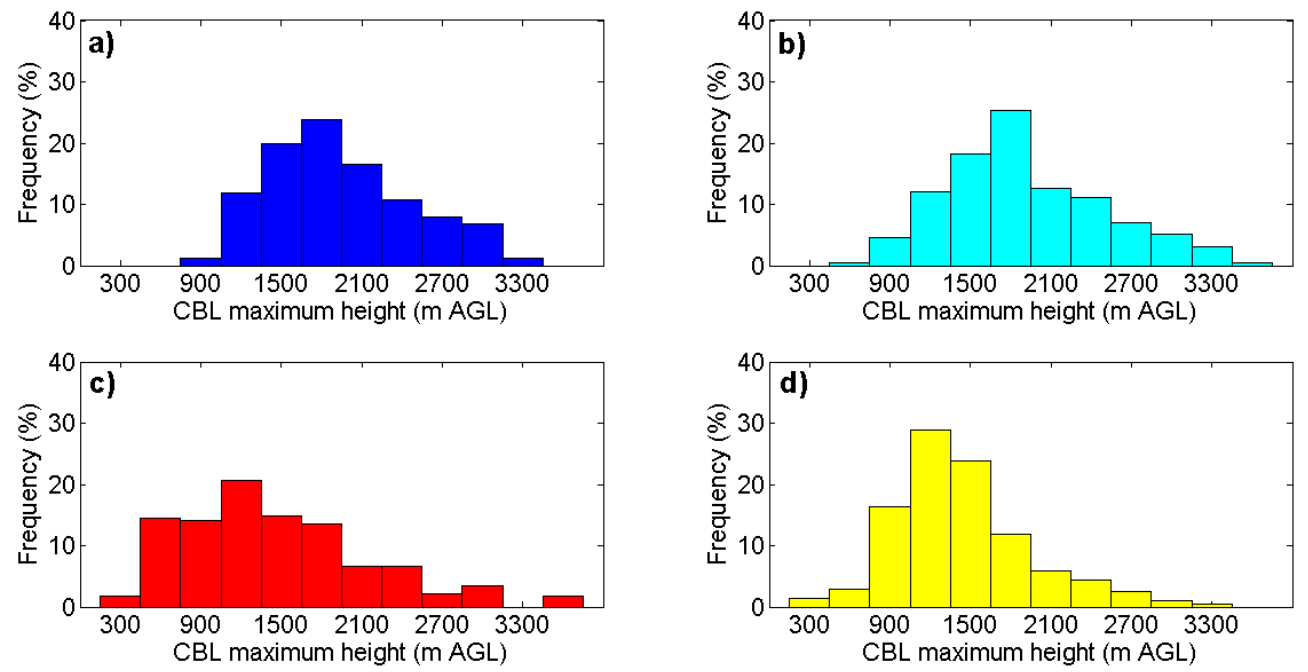

Fig. 6. Histograms for measured and modelled PBL top daily maximum heights during 2010, (a) Polly XT, (b) ECMWF, (c) SAWS and (d) TAPM

comparison for days when PBL maximum height was considered to be detected reliably with the lidar, i.e. when measurement time was distributed over separate hours before and after the solar noon to detect PBL evolution and no wet removal was observed. As is evident in Fig. 7a, the tendencies of over- or underestimation in PBL top height altered between the change between the dry and the rainy season for the models. In comparison to lidar measurements, the ECMWF and the SAWS models tend to show larger overestimation during the rainy season, while TAPM gives larger values than the lidar. This is mainly due to the effect of increased cloudiness. The monthly differences seem to have similar seasonal pattern for each of the models. Similar plots (Fig. 7b-d) are presented separately for the 11:00, 14:00 and 17:00 time slots. In general, the differences between the methods are largest at 11:00 when mixing starts.

\subsubsection{Ground-based lidar-Polly ${ }^{\mathrm{XT}}$}

In the subsequent sections, we will present the lidar-model comparison results in more detail. As mentioned earlier, the lidar data set was selected as the base for the comparison with the other techniques, mainly due to its good temporal and vertical resolution. In addition, the focus of this study was to investigate the PBL characteristics at the Elandsfontein measurement site where the lidar was located and thus the models were centred to it. The drawbacks of the ground-based lidar are associated with the technical complexity of the instrument, sensitivity for rain and complex aerosol structures. Still, the PBL top height was detected in about $86 \%$ of all the measurement data ( $42 \%$ of the total time). In general, the lidar data have more variation during the rainy season, which may partly explain the large differences observed in October (Fig. 5). Maintenance was carried out during two months in the rainy season (December and January) resulting in a smaller data set for that particular season, which could have affected the observations of monthly and seasonal PBL characteristics.

\subsubsection{ECMWF}

The ECMWF model shows the best correlation to lidar measurements (Figs. 5, 7 and 8) with only $19.8 \%$ mean absolute difference, when October is excluded from the comparison $-30 \%$ ECMWF PBL top values are within $\pm 20 \%$, while $72 \%$ are within $\pm 50 \%$ of the lidar values. When comparing only the PBL top height at 14:00 the corresponding values are $61 \%$ and $89.6 \%$. The ECMWF model tends to evaluate the PBL top a bit higher than the PBL top measured with the Polly ${ }^{\mathrm{XT}}$ (in $62.5 \%$ of the cases). A clear seasonal pattern is observed in differences between the two methods (Fig. 7). The best agreement is found between March and July, i.e. during the dry season. A plausible explanation for this is the similar pattern observed in global radiation daily maxima (see Fig. 2b). The PBL top evaluation by the ECMWF model is based on the strength of convection, and therefore the model is sensitive to changes in radiation levels. The monthly averages of daily maximum global radiation decrease strongly during autumn from $1000 \mathrm{Wm}^{-2}$ in March to $760 \mathrm{Wm}^{-2}$ in April. The average daily maximum intensity remains below $800 \mathrm{Wm}^{-2}$ until September, after which it increases to $920 \mathrm{Wm}^{-2}$ and further increases to over $1000 \mathrm{Wm}^{-2}$ for the rest of the year. Figure 8a shows the scatter plot comparison between the lidar and the ECMWF model for convective conditions (684 common data points), in other words for data points at 11:00,14:00 and 17:00. The fit of the slope is 0.85 and $R 0.62$. 

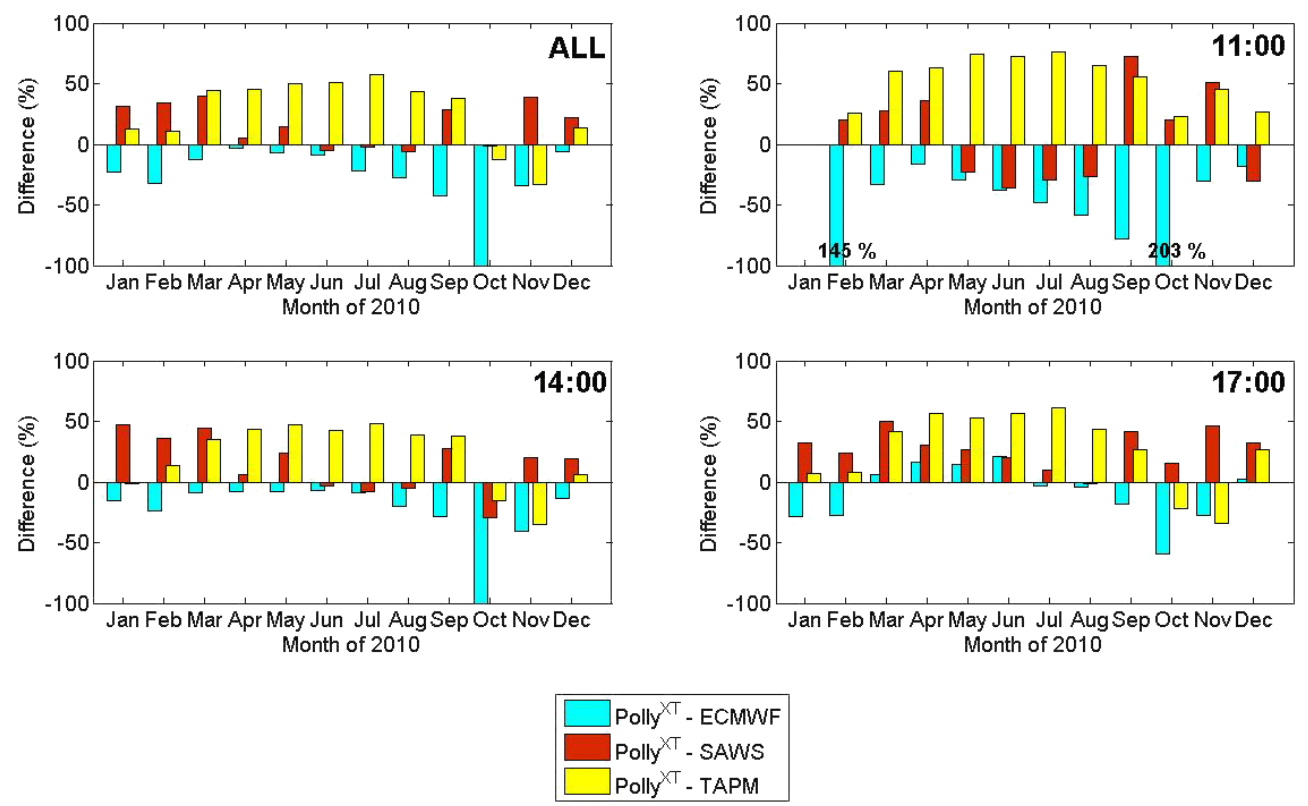

Fig. 7. Monthly mean differences in PBL height from the lidar and each model: (a) all values between 11:00-17:00, (b) 11:00, (c) 14:00 and (d) 17:00.
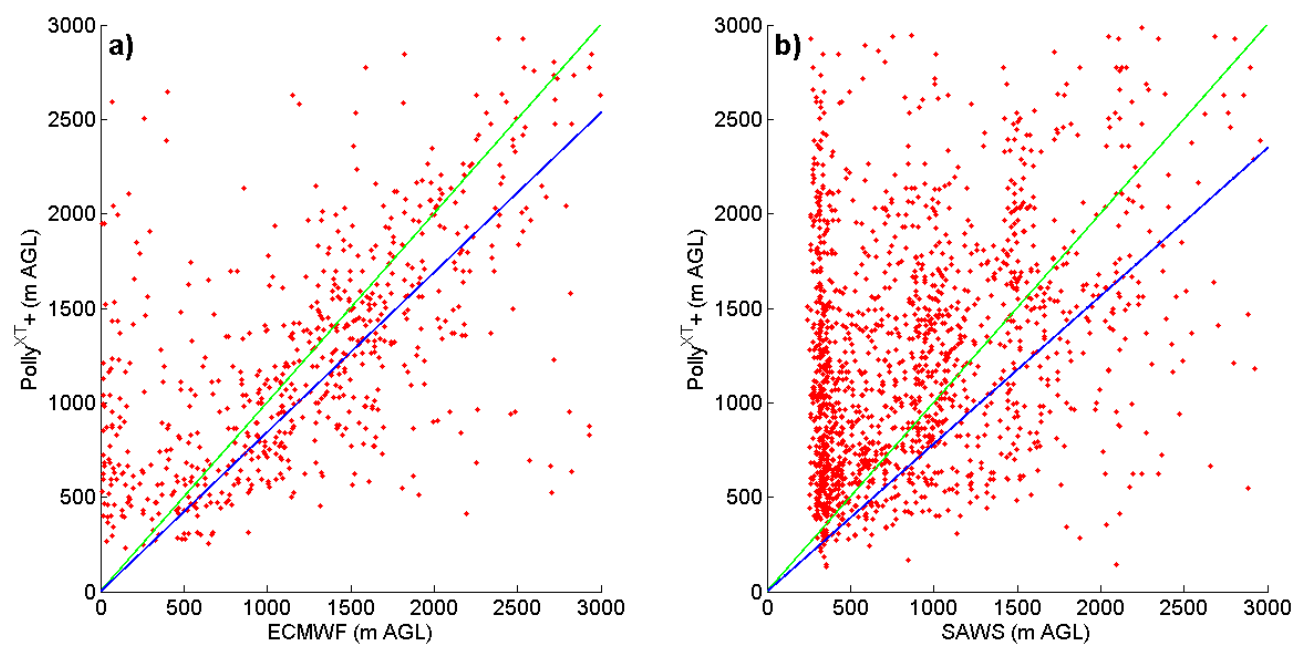

Fig. 8. Scatter plot between Polly XT and ECMWF (a) and Polly XT and the SAWS-operated model (b) for convective (08:00-17:00) conditions. The green and the blue lines represent a $1: 1$ correspondence and linear fit to data, respectively.

\subsubsection{SAWS}

The SAWS operated model shows the second best correlation with Polly ${ }^{\mathrm{XT}}$ (Figs. 5, 7 and 8) with a mean absolute difference of $20.6 \%$ during daytime. About $18 \%$ of the SAWS PBL top values are within $\pm 20 \%$, while $48.2 \%$ are within $\pm 50 \%$ of the lidar values. When comparing only the PBL at 14:00, the corresponding values are $25.7 \%$ and $58.7 \%$. The SAWS model shows a smaller difference to the Polly ${ }^{\mathrm{XT}}$ lidar measurement during the dry season. The SAWS model values were lower than the lidar values in $23.9 \%$ of the cases and smaller than the ECMWF values in $21.8 \%$ of the cases.
The slope of the fitted line in Fig. $8 \mathrm{~b}$ is 0.78 but the $R$ is smaller when compared to the ECMWF model, 0.24, with 1635 data points.

To analyse the results in more detail, the model temperature and wind speed were compared to the ground-based measurements. The model temperature compared reasonably well to the measurements, with the mean relative difference being about $8 \%$. However, the SAWS model tends to underestimate the wind speed. The mean relative difference in the wind speed was $46 \%$ and $45 \%$ of the model wind speeds were within $\pm 50 \%$ of the measured values. In addition, about $89 \%$ of the model values were smaller than 
the measured wind speed. The underestimation of the wind speed may affect the higher-altitude weather parameters in the model and therefore have consequences for the PBL top height determination.

\subsubsection{TAPM}

Comparison between Polly ${ }^{\mathrm{XT}}$ and TAPM indicates systematic underestimation of PBL top height by the model (Figs. 5 and 7), with ten months showing higher values for the Polly ${ }^{\mathrm{XT}}$ measurements. The mean relative difference in the comparison between the lidar and TAPM is $36.5 \%$. The modelled values are smaller than PBL top heights measured with the lidar for $91.7 \%$ of the cases. This is also observed by comparing TAPM to the other models. TAPM model values are smaller than the ECMWF PBL top height values for $94.6 \%$ of the cases. A different seasonal behaviour is observed compared to the lidar and to the ECMWF model (Fig. 7). In a similar way as the ECMWF model, TAPM estimates the PBL height through the strength of convection and the differences to the lidar measurement indicate that increasing global radiation intensity improves the performance of the model. Hence, the relative differences compared to the lidar measurements are significantly lower in warmer months (October-February). However, the number of measurement days was low in January and November with only five and three days, respectively. Just $15.6 \%$ of the TAPM PBL top height values are within $\pm 20 \%$ and $59.7 \%$ are within $\pm 50 \%$ of the lidar values. When comparing TAPM with the ECMWF model, the corresponding $( \pm 20 \%$ and $\pm 50 \%$ ) values were $9.3 \%$ and $40 \%$.

In order to explain the observed differences, the model temperature, radiation and wind speed were compared to the ground-based measurements. The model temperature and global radiation compared well with the measurements. The mean absolute difference in temperature values between the model and measurements was about $4 \%$. However, the model underestimates the wind speed significantly. The mean absolute difference was $23 \%$ and $60 \%$ of the model wind speeds were within $\pm 50 \%$ of the measured values. About $74 \%$ of the model values were smaller than the measured wind speed. The underestimation of the wind speed probably leads to underestimation of the vertical wind and turbulence and thus underestimation of the PBL top height. This may partly explain the observed differences.

\subsubsection{Space-borne lidar}

Comparisons of PBL top heights between ground-based Polly ${ }^{\mathrm{XT}}$ lidar and space-borne CALIOP lidar have been performed for the 29 common cases. As previously stated, the CALIOP overpasses were between 60 and $110 \mathrm{~km}$ from the lidar site. The scatter plot between CALIOP and Polly ${ }^{\mathrm{XT}}$ lidar derived PBL heights shows a good correlation with a correlation coefficient of 0.88 (Fig. 9). The majority of our data

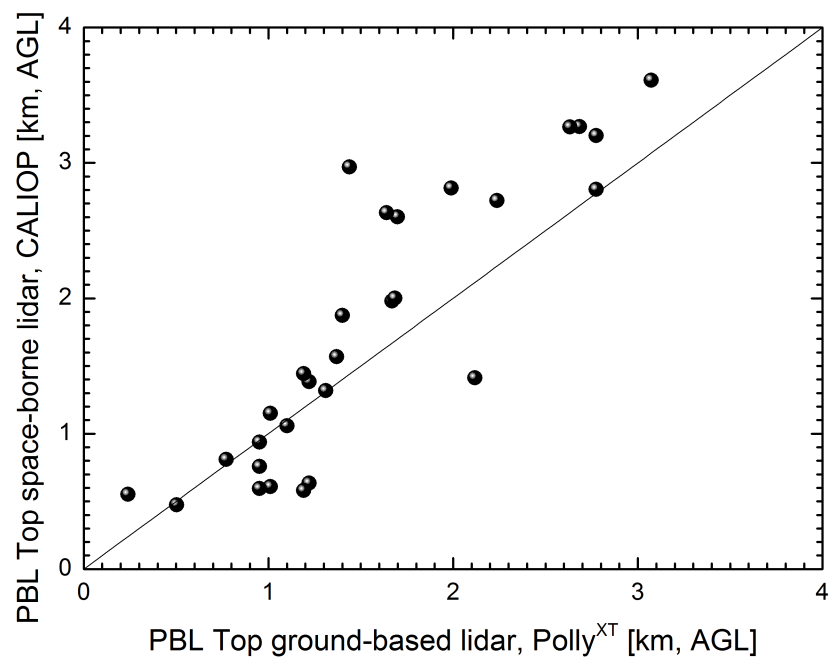

Fig. 9. PBL top comparison of 29 common PBL top height observation cases for Polly $\mathrm{XT}$ and CALIOP data.

accounts for PBL heights lower than $3 \mathrm{~km}$. The overestimation seems to be larger for larger PBL top heights $(>1.5 \mathrm{~km})$ (see Fig. 9), rather than being related to the distance between the overpass and the lidar station or the time difference. In the cases when CALIOP detected two or more layers, we considered the top of the first layer from the ground to be the PBL top height. However, in three cases (out of the total 29), the top of the second layer was taken, since it was obvious from the attenuated backscatter profiles of CALIOP that the first layer corresponds to a layer inside the PBL. Based on this comparison data set, the altitude of the first layer of level 2 aerosol layer product can be considered being consistent with the PBL top height determined with ground-based lidar in $90 \%$ of the cases.

\subsection{Diurnal PBL cycle}

Figure 10 shows the annual average of diurnal PBL evolution for the common data points. The sunrise times varied between 05:07 and 06:56, while sunset times ranged between 17:23 and 19:05 - these time are indicated with the shaded areas in Fig. 10. The lidar measurements cover both daytime CBL and nocturnal RL heights, similarly to the SAWS model.

According to the Polly ${ }^{\mathrm{XT}}$ measurements, the daily evolution of the CBL starts approximately 3 to $4 \mathrm{~h}$ after sunrise and a daily PBL maximum top height is reached on average $3.5 \mathrm{~h}$ after the solar noon (solar noon at 11:51-12:14 with seasonal dependence). The ECMWF model evaluates the PBL height only during convective conditions (daytime) and therefore the night-time result for PBL height is low. Due to the $3 \mathrm{~h}$ temporal resolution, the simulated daily maximum heights of the PBL top are reached at 14:00 or 17:00 on all days studied, which may have a $1.5 \mathrm{~h}$ difference between the maximum PBL top height time measured with the lidar (15:30 on 


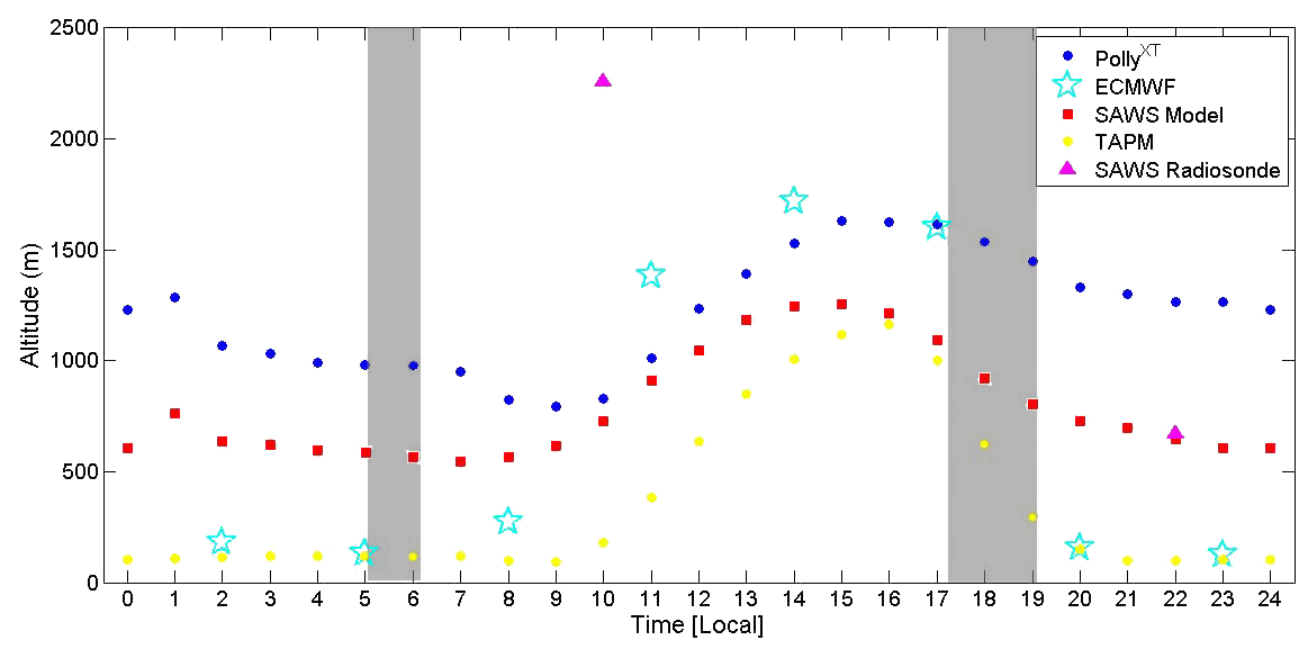

Fig. 10. PBL diurnal cycle observed in Elandsfontein during 2010. The grey shading indicates the times of sunrise and sunset.

average). From Figure 10, one can identify that the PBL development starts earlier and is stronger in the ECMWF model compared to the Polly ${ }^{\mathrm{XT}}$ data (see values between 08:00 and 17:00). During the day the best correlations of 0.46 and 0.52 were found between the two methods at 14:00 and 17:00, respectively. This correlation was only 0.16 at 11:00.

TAPM, with a $1 \mathrm{~h}$ temporal resolution follows the CBL evolution well despite systematic underestimation of PBL height, which was discussed in Sect. 4.3.4. The SAWS model gives both CBL and RL heights, and the results agree well for the latter in comparison to lidar measurement. The BRN method used in the SAWS model is sensitive enough to detect inversion layers that occur on the RL top under stable conditions, i.e. non-convective atmospheric conditions. The same feature is also observed in the radiosonde data. The 22:00 soundings agree better with the lidar measurement than the soundings at 10:00.

\subsection{Planetary boundary layer characteristics}

This section summarises the PBL characteristics determined with the Polly ${ }^{\mathrm{XT}}$ lidar for 2010 at Elandsfontein. The discussion of the SBL is based on the ECMWF and TAPM models. The presented features could be generalised to some extent for different years (the year 2010 average temperature was close to the long-term averages) in southern Africa in areas with similar surface properties and solar radiation. As shown in Fig. 5, the seasonal cycle of the PBL top height is relatively explicit and follows the cycle of solar radiation (Fig. 2b). On average, the PBL top was highest in spring (September and October with heights of 2170 and $2260 \mathrm{~m}$ with standard deviations of $790 \mathrm{~m}$ and $940 \mathrm{~m}$, respectively), while it was the lowest in winter (May-August with heights of 1450-1790 m) and in January (1210 m), which may be due to low number of measurement days (5). The standard deviations of monthly averages were from $17 \%$ (January) up to $42 \%$ (October), which indicates high variability between the PBL daily top maxima. The diurnal cycle is also well pronounced (Fig. 10). The evolution of the observed CBL started approximately 3 to $4 \mathrm{~h}$ after sunrise and the daily PBL top maximum was reached about $3.5 \mathrm{~h}$ after the solar noon. The models following the CBL (ECMWF and TAPM) show that the SBL top during night-time is on average $160 \mathrm{~m}$ (monthly averages varying from 70 to $270 \mathrm{~m}$ ). The RL top (defined by the lidar) remains on average at $890 \mathrm{~m}$ during the night (monthly averages from 450 to $1370 \mathrm{~m}$ ). The low SBL heights observed support earlier findings in South Africa that indicated that the night-time domestic pollution originating mainly from informal and semi-formal settlements is trapped near the surface of the earth and heavily impacts local air quality (Venter et al., 2012). The industrial emissions are most probably released and lifted to the RL because of tall stacks. As an example, all but two power plants owned by the national power company have stacks rising up to $200 \mathrm{~m}$ or more (Bethlehem and Goldblatt, 1997). Therefore the immediate effect of industrial emissions on air quality is smaller during the night, when the SBL is low.

\subsection{PBL growth rates}

Figure 11 presents the PBL growth rates determined in 2010. All modelled values (Fig. 11b-d) are in relatively good agreement with the Polly ${ }^{\mathrm{XT}}$ measurements presented in Fig. 10a. The modes of the lidar, the ECMWF model (Fig. 11b) and the SAWS model (Fig. 11c) are 120$180 \mathrm{~m} \mathrm{~h}^{-1}$ with frequencies of $32.2 \%, 34.5 \%$, and $39.7 \%$, respectively. The corresponding median values for the lidar, the ECMWF model and the SAWS model are 183, 167 and $163 \mathrm{~m} \mathrm{~h}^{-1}$ with standard deviations of 84,76 and $74 \mathrm{~m} \mathrm{~h}^{-1}$, respectively. The median of TAPM (Fig. 11d) at $172 \mathrm{~m} \mathrm{~h}^{-1}$ (standard deviation $81 \mathrm{~m} \mathrm{~h}^{-1}$ ) agrees with the other methods although the standard deviation is the second largest after 

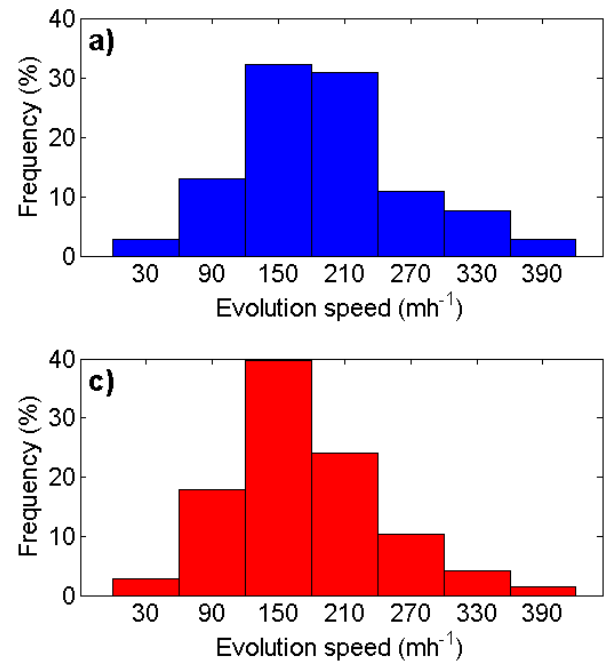
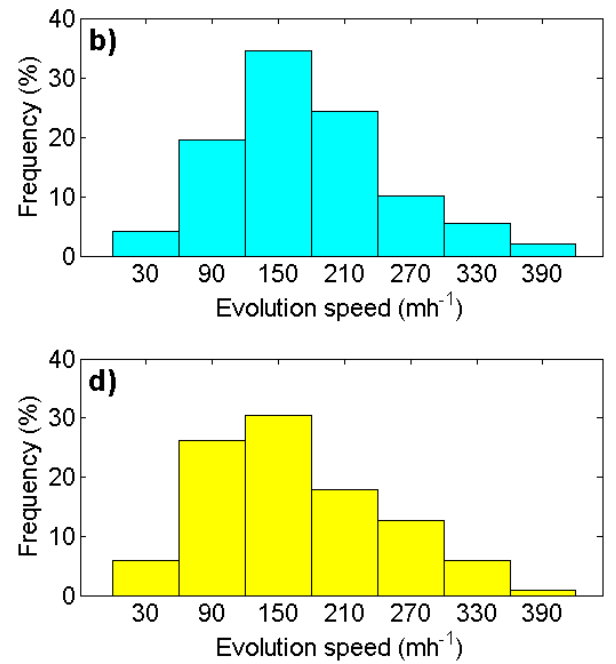

Fig. 11. PBL growth rates during the comparison period: (a) PollyXT, (b) ECMWF, (c) SAWS 2 and (d) TAPM.

Polly ${ }^{\mathrm{XT}}\left(81 \mathrm{~m} \mathrm{~h}^{-1}\right)$ and $30.5 \%$ of the values are in the range of $120-180 \mathrm{~m} \mathrm{~h}^{-1}$. The large percentage of values below the $120-180 \mathrm{~m} \mathrm{~h}^{-1}$ range, $32.4 \%$, can partly explain the previous result of systematical underestimation of the PBL top height by TAPM. The length of the growth period of the TAPM was typically similar to that of the Polly ${ }^{\mathrm{XT}}$ measurements with an average of $6.8 \mathrm{~h}$ (Polly ${ }^{\mathrm{XT}} 6.7 \mathrm{~h}$ ).

\section{Comparison to other locations}

This study is the first long-term study of PBL top heights and PBL growth rates in the Southern Hemisphere. The average PBL top height of $1.4 \pm 0.5 \mathrm{~km}$ a.g.l. under convective conditions (08:00-17:00) is comparably high, with its highest values and variability in spring $(1.6 \pm 0.7 \mathrm{~km})$ and lower values in the other seasons $(1.3 \mathrm{~km})$. Within Europe, maximum values occurred during summer, e.g. $1.8 \mathrm{~km}$ in Leipzig, Germany (Baars et al., 2008) and $1.3 \mathrm{~km}$ in Granada, Spain (Granados-Muñoz et al., 2012). In winter both of these studies showed values around $0.8 \mathrm{~km}$. Chen et al. (2001) have reported PBL top heights of $1.0 \mathrm{~km}$ for a site in Japan in spring and autumn, while PBL top heights were 0.4 and $0.7 \mathrm{~km}$ in winter and summer, respectively. Hänel et al. (2012) have reported night-time RL top heights of 0.7 to $1.1 \mathrm{~km}$ in the vicinity of Beijing, China, with maximum values in spring and summer.

The PBL growth rates found in this study compare well with other locations and maximum values coincide with the maximum PBL top heights. PBL growth rates were, thus, highest in spring with $220 \pm 100 \mathrm{~m} \mathrm{~h}^{-1}$ and lower during the other seasons. On average, growth rates between 100 and 300 $\mathrm{m} \mathrm{h}^{-1}$ were found. Baars et al. (2008) found growth rates of 100 to $300 \mathrm{~m} \mathrm{~h}^{-1}$ most of the year and 400 to $500 \mathrm{~m} \mathrm{~h}^{-1}$ in summer. Chen et al. (2001) reported lower growth rates of 30 to $100 \mathrm{~m} \mathrm{~h}^{-1}$ with peak values of $140 \mathrm{~m} \mathrm{~h}^{-1}$ in autumn.

\section{Summary and conclusions}

One year of PBL top height observations done with Polly XT lidar were compared with three atmospheric models, radiosonde measurements and CALIOP space-borne lidar in South Africa. It was shown that the lidar is suitable for continuous measurements of daytime PBL and night-time RL with high temporal data coverage. We had data coverage of $49 \%$ for the complete sampling period (60\% if maintenance breaks are excluded). For the lidar PBL top height determination the WCT method performed well despite frequent complex vertical aerosol layer structures caused by large emissions from large point sources and biomass burning. The lidar detected the PBL top height for $86 \%$ of all the measurements ( $42 \%$ of the total time). The best performance in data coverage and PBL height detection was observed during the dry season (April-September), when rain and cloudy conditions had only a minor impact on the measurements and aerosol concentrations were the highest.

The comparison between Polly ${ }^{\mathrm{XT}}$ lidar and radiosonde measurements showed large variation. However, there are a few aspects which are likely to contribute to the discrepancies between the two methods. Firstly, the radiosonde launch site (Pretoria) is $120 \mathrm{~km}$ from the lidar site and secondly, we found cases when entirely stable troposphere resulted in clear failure in PBL height determination by the BRN method. Despite their limitations in temporal resolution and PBL top height determination method, radiosondes have been routinely used for decades and therefore are a valuable method for long-term climatology analyses. 
The results from the ECMWF model indicated the best agreement with the lidar data in the annual PBL cycle. Hence, the model predicts the daily PBL top maximum height well despite its $3 \mathrm{~h}$ temporal resolution. In addition, the PBL growth rates agree well with those derived from lidar data. The performance of the model is the best during the dry season (May-June) with relatively small average overestimation $(8.2 \%)$ of PBL top height when all daytime values (11:00, 14:00 and 17:00) are compared with the Polly XT data. During spring and summer (October-February) the differences varied more, which is most probably a combined result from weather-related limitations (clouds and precipitation) of the lidar measurements, as well as maintenance that was done during two summer months. Both the aforementioned reasons lead to a smaller lidar data set during this rainy season.

The SAWS model performed well in general, notwithstanding the fixed pressure levels with $50 \mathrm{hPa}$ intervals, which results in vertical resolution of about $500 \mathrm{~m}$ near the surface. The model performed second best with regard to daytime PBL top height evaluation with only slightly larger mean absolute difference than the lidar measurements $(20.6 \%)$. Similar uncertainties were observed as for the radiosondes, but the overall performance of the SAWS model was relatively good compared to the results from Polly ${ }^{\mathrm{XT}}$ and the ECMWF model. However, the SAWS model underestimates the wind speed strongly. About $89 \%$ of the model values were smaller than the measured wind speed. The underestimation of the wind speed may affect the higher altitude weather parameters in the model and therefore have consequences for the PBL top height determination.

The TAPM has the densest vertical grid of the studied models, but it systematically underestimated the PBL top height, possibly due to its determination method. The mean relative difference in the comparison between lidar and TAPM is $34.7 \%$. The modelled values are smaller than PBL top heights measured with the lidar for $92 \%$ of the cases. The model temperature and global radiation compared well with the measurements, but the model underestimates the wind speed strongly. The mean absolute difference was $23 \%$ and about $74 \%$ of the model values were smaller than the measured wind speed. The underestimation of the wind speed probably leads to underestimation of the vertical wind and turbulence, thus underestimation of the PBL top height. This may partly explain the observed differences.

The CALIOP level 2 aerosol layer product compares well with the PBL top heights from Polly ${ }^{\mathrm{XT}}$ lidar. For the total number of 29 cases, the correlation coefficient is 0.88 and for $90 \%$ of the studied cases, the altitude of the first layer of level 2 aerosol layer product can be considered as the PBL top.

The notable differences found between the methods for PBL top height determination show that one has to be careful when using a modelled value for a specific location and time. Moreover, the use of radiosonde data from a distant site should be considered carefully. Different approaches could even produce different seasonal cycles, as was observed at the studied site. The elevation of the area and the hilly surroundings (surface elevation varies within $200 \mathrm{~m}$ ) may be responsible for some of the differences depending on the model grid (even though it was centred at our site). If the PBL top heights are used in air quality modelling, the possible unrealistic PBL top height variations will be transferred directly to the air quality results through the erroneous size of the mixing volume for aerosols. More direct measurements of the PBL top heights e.g. with lidars can be used to verify the models. For more detailed model verification studies we recommend the usage of all available model data products and parameters in order to cover all the drivers of PBL dynamics, such as temperature, wind speed, solar radiation, vertical heat flux, surface reflectivity and modelled vegetation parameters.

Acknowledgements. This work has been partly supported by the European Union (in project EUCAARI). The authors acknowledge the staff of the North-West University for valuable assistance and routine maintenance of the lidar. We also acknowledge Eskom and Sasol for their logistical support for measurements at Elandsfontein.

Edited by: L. Ganzeveld

\section{References}

Althausen, D., Engelmann, R., Baars, H., Heese, B., Ansmann, A., Müller, D., and Komppula, M.: Portable Raman Lidar PollyXT for Automated Profiling of Aerosol Backscatter, Extinction, and Depolarization, J. Atmos. Ocean. Technol., 26, 23662378, 2009.

Amiridis, V., Melas, D., Balis, D. S., Papayannis, A., Founda, D., Katragkou, E., Giannakaki, E., Mamouri, R. E., Gerasopoulos, E., and Zerefos, C.: Aerosol Lidar observations and model calculations of the Planetary Boundary Layer evolution over Greece, during the March 2006 Total Solar Eclipse, Atmos. Chem. Phys., 7, 6181-6189, doi:10.5194/acp-7-6181-2007, 2007.

Ansmann, A., Riebesell, M., Wandinger, U., Weitkamp, C., Voss, E., Lahmann, W., and Michaelis, W.: Combined Raman elasticbackscatter lidar for vertical profiling of moisture, aerosol extinction, backscatter, and lidar ratio, Appl. Phys. B55, 18-28, 1992.

Ansmann, A., Baars, H., Tesche, M., Müller, D., Althausen, D., Engelmann, R., Pauliquevis, T., and Artaxo, P.: Dust and smoke trasport from Africa to South America: Lidar profiling over Cape Verde and the Amazon rainforest, Geophys. Res. Lett., 36, L11802, doi:10.1029/2009GL037923, 2009.

Ansmann, A., Petzold, A., Kandler, K., Tegen, I., Wendisch, M., Müllet, D., Weinzierl, B., Müller, T., and Heintzenberg, J.: Saharan Mineral Dust Experiments SAMUM-1 and SAMUM-2: what have we learned? Tellus 63B, 403-429, doi:10.1111/j.16000889.2011.00555.x, 2011.

Baars, H., Ansmann, A., Engelmann, R., and Althausen, D.: Continuous monitoring of the boundary-layer top with lidar, Atmos. Chem. Phys., 8, 7281-7296, doi:10.5194/acp-8-7281-2008, 2008. 
Bethlehem, L. and Goldblatt, M.: The Bottom Line, Industry and the Environment in South Africa. University of Cape Town Press, International Development Research Centre, ISBN 0-88936-830-9, 1997.

Brooks, I. M.: Finding Boundary Layer Top: Application of a Wavelet Covariance Transform to Lidar Backscatter Profiles, J. Atmos. Ocean. Technol., 20, 1092-1195, 2003.

Campbell, J. R., Welton, E., Spinhirne, J. D., Ji, Q., Tsay, S. C., Piketh, S. P., and Barenbrug, M.: Micropulse lidar observations of tropospheric aerosols over northeastern South Africa during the ARREX and SAFARI 2000 dry season experiments, J. Geophys. Res., 108, 8497-8530, doi:10.1029/2002JD002563, 2003.

Chen, W., Kuze, H., Uchiyama, A., Suzuki, Y., and Takeuchi, N.: One-year observation of urban mixed layer characteristics at Tsukuba, Japan using a micro pulse lidar, Atmos. Environ., 35, 4273-4280, doi:10.1016/S1352-2310(01)00181-9, 2001.

Cimini, D., De Angelis, F., Dupont, J.-C., Pal, S., and Haeffelin, M.: Mixing layer height retrievals by multichannel microwave radiometer observations, Atmos. Meas. Tech., 6, 2941-2951, doi:10.5194/amt-6-2941-2013, 2013.

ECMWF: IFS Documentation - Cy36r1, part 5: Ensemble prediction system, ECWMF, 2010a.

ECMWF: IFS Documentation - Cy36r1, part 4: Physical processes, ECMWF, 2010b.

ECMWF: IFS Documentation - Cy36r1, ECMWF, 2010c.

Formenti, P., Winkler, H., Fourie, P., Piketh, S., Makgopa, B., Helas, G., and Andreae, M. O.: Aerosol optical depth over a remote semi-arid region of South Africa from spectral measurements of the daytime solar extinction and the nighttime stellar extinction, Atmos. Res., 62, 11-32, doi:10.1016/S0169-8095(02)00021-2, 2002.

Formenti, P., Elbert, W., Maenhaut, W., Haywood, J., Osborne, S., and Andreae, M. O.: Inorganic and carbonaceous aerosols during the Southern African Regional Science Initiative (SAFARI 2000) experiment: Chemical characteristics, physical properties, and emission data for smoke from African biomass burning, J. Geophys. Res., 108, 8488, doi:10.1029/2002JD002408, 2003.

Granados-Muñoz, M. J., Navas-Guzmán, F., Bravo-Aranda, J. A., Guerrero-Rascado, J. L., Lyamani, H., Fernandez-Galvez, J., and Alados-Arboledas, L.: Automatic determination of the planetary boundary layer height using lidar: one-year analysis over Southeastern Spain., J. Geophys. Res., 117, D18208, doi:10.1029/2012JD017524, 2012.

Groß, S., Gasteiger, J., Freudenthaler, V., Wiegner, M., Geiß, A., Schladitz, A., Toledano, C., Kandler, K., Tesche, M., Ansmann, A. and Wiedensohler, A.: Characterization of the planetary boundary layer during SAMUM-2 by means of lidar measurements. Tellus 63B, 695-705, doi:10.1111/j.16000889.2011.00557.x, 2011.

Haeffelin, M., Angelini, F., Morille, Y., Martucci, G., Frey, S., Gobbi, G. P., Lolli, S., O’Dowd, C. D., Sauvage, L., XuerefRémy, I., Wastine, B., Feist, D. G.: Evaluation of Mixing-Height Retrievals from Automatic Profiling Lidars and Ceilometers in View of Future Integrated Networks in Europe, Bound.-Lay. Meteorol., 143, 49-75, doi:10.1007/s10546-011-9643-z, 2012.

Hennemuth, B. and Lammert, A.: Determination of the atmospheric boundary layer height from radiosonde and lidar backscatter, Bound.-Lay. Meteorol., 120, 181-200, doi:10.1007/s10546-0059035-3, 2006.
Hurley, P.: TAPM V4. Part 1: Technical Description. CSIRO Marine and Atmospheric Research Paper No. 25, October 2008. ISBN: 978-1-921424-71-7, 2008.

Hurley, P. J., Physick, W. L., and Luhar, A. K.: TAPM: a practical approach to prognostic meteorological and air pollution modelling, Environ. Model. Softw., 20, 737-752, $2005 \mathrm{a}$.

Hurley, P., Physick, W., Luhar, A., and Edwards, M.: The Air Pollution Model (TAPM) Version 3. Part 2: Summary of some verification studies, CSIRO, Atmos. Res., 72, 20-36, 2005b.

Hurley, P., Edwards, M., and Luhar, A.: TAPM V4. Part 2: Summary of Some Verification Studies. CSIRO Marine and Atmospheric Research Paper No. 26, October 2008, ISBN: 978-1-921424-724, 2008.

Hänel, A., Baars, H., Althausen, D., Ansmann, A., Engelmann, R., and Sun, J. Y.: One-year aerosol profiling with EUCAARI Raman lidar at Shangdianzi GAW station: Beijing plume and seasonal variations, J. Geophys. Res., 117, D13201, doi:10.1029/2012JD017577, 2012.

Johansson, C. and Bergström, H.: An auxiliary tool to determine the height of the boundary layer, Bound.-Lay. Meteorol., 115, 423432, doi:10.1007/s10546-004-1424-5, 2005.

Jordan, N. S., Hoff, R. M., and Bacmeister, J. T.: Validation of Goddard Earth Observing System-version 5 MERRA planetary boundary layer heights using CALIPSO, J. Geophys. Res., 115, D24218, doi:10.1029/2009JD013777, 2010.

Kulmala, M., Asmi, A., Lappalainen, H. K., Baltensperger, U., Brenguier, J.-L., Facchini, M. C., Hansson, H.-C., Hov, Ø., O’Dowd, C. D., Pöschl, U., Wiedensohler, A., Boers, R., Boucher, O., de Leeuw, G., Denier van der Gon, H. A. C., Feichter, J., Krejci, R., Laj, P., Lihavainen, H., Lohmann, U., McFiggans, G., Mentel, T., Pilinis, C., Riipinen, I., Schulz, M., Stohl, A., Swietlicki, E., Vignati, E., Alves, C., Amann, M., Ammann, M., Arabas, S., Artaxo, P., Baars, H., Beddows, D. C. S., Bergström, R., Beukes, J. P., Bilde, M., Burkhart, J. F., Canonaco, F., Clegg, S. L., Coe, H., Crumeyrolle, S., D’Anna, B., Decesari, S., Gilardoni, S., Fischer, M., Fjaeraa, A. M., Fountoukis, C., George, C., Gomes, L., Halloran, P., Hamburger, T., Harrison, R. M., Herrmann, H., Hoffmann, T., Hoose, C., Hu, M., Hyvärinen, A., Hõrrak, U., Iinuma, Y., Iversen, T., Josipovic, M., Kanakidou, M., Kiendler-Scharr, A., Kirkevåg, A., Kiss, G., Klimont, Z., Kolmonen, P., Komppula, M., Kristjánsson, J.-E., Laakso, L., Laaksonen, A., Labonnote, L., Lanz, V. A., Lehtinen, K. E. J., Rizzo, L. V., Makkonen, R., Manninen, H. E., McMeeking, G., Merikanto, J., Minikin, A., Mirme, S., Morgan, W. T., Nemitz, E., O’Donnell, D., Panwar, T. S., Pawlowska, H., Petzold, A., Pienaar, J. J., Pio, C., Plass-Duelmer, C., Prévôt, A. S. H., Pryor, S., Reddington, C. L., Roberts, G., Rosenfeld, D., Schwarz, J., Seland, ø., Sellegri, K., Shen, X. J., Shiraiwa, M., Siebert, H., Sierau, B., Simpson, D., Sun, J. Y., Topping, D., Tunved, P., Vaattovaara, P., Vakkari, V., Veefkind, J. P., Visschedijk, A., Vuollekoski, H., Vuolo, R., Wehner, B., Wildt, J., Woodward, S., Worsnop, D. R., van Zadelhoff, G.-J., Zardini, A. A., Zhang, K., van Zyl, P. G., Kerminen, V.-M., S Carslaw, K., and Pandis, S. N.: General overview: European Integrated project on Aerosol Cloud Climate and Air Quality interactions (EUCAARI) - integrating aerosol research from nano to global scales, Atmos. Chem. Phys., 11, 13061-13143, doi:10.5194/acp11-13061-2011, 2011. 
Laakso, L., Vakkari, V., Virkkula, A., Laakso, H., Backman, J., Kulmala, M., Beukes, J. P., van Zyl, P. G., Tiitta, P., Josipovic, M., Pienaar, J. J., Chiloane, K., Gilardoni, S., Vignati, E., Wiedensohler, A., Tuch, T., Birmili, W., Piketh, S., Collett, K., Fourie, G. D., Komppula, M., Lihavainen, H., de Leeuw, G., and Kerminen, V.-M.: South African EUCAARI measurements: seasonal variation of trace gases and aerosol optical properties, Atmos. Chem. Phys., 12, 1847-1864, doi:10.5194/acp-12-1847-2012, 2012.

Lai, L. and Cheng, W. L.: Air quality influenced by urban heat island coupled with synoptic weather patterns, Sci. Total Environ., 4, 2724-2733, 2009.

Landman, S., Engelbrecht, F. A., Engelbrecht, C. J., Dyson, L. L., and Landman, W.: A short-range prediction system based on a multi-model approach, Water SA, 38, ISSN 0378-4738, 2012.

Liu, L.: Improving GCM Aerosol Climatology using satellite and ground based measurements, paper presented at 15th ARM Science Team Meeting, Atmos. Radiat. Meas. (ARM) Program, Daytona Beach, Florida, 14-18 March, 2005.

Lourens, A. S. M., Beukes, J. P., van Zyl, P. G., Fourie, G. D., Burger, J. W., Pienaar, J. J., Read, C. E. and Jordaan, J. H. L., Spatial and Temporal assessment of Gaseous Pollutants in the Mpumalanga Highveld of South Africa, South Afr. J. Sci., 107, 8 pp. doi:10.4102/sajs.v107i1/2.269, 2011.

Lourens, S. M., Butler, T. M., Beukes, J. P., van Zyl, P. G., Beirle, S., Wagner, T., Heue, K.-P., Pienaar, J. J., Fourie, G. D., and Lawrence, M. G.: Re-evaluating the $\mathrm{NO}_{2}$ hotspot over the South African Highveld, South Afr. J. Sci., 108, 6 pp.. doi:10.4102/sajs.v108i11/12.1146, 2012.

Luhar, A. K. and Hurley P. J.: Application of a prognostic model TAPM to sea-breeze flows, surface concentrations, and fumigating plumes, Environ. Model. Softw., 19, 591-601, 2004.

Matthias, V., Balis, D., Bösenberg, J., Eixmann, R., Iarlori, M., Komguem, L., Mattis, I., Papayannis, A., Pappalardo, G., Perrone, M. R., and Wang, X.: Vertical aerosol distribution over Europr: Statistical analysis of Raman lidar data from 10 European Aerosol Research Lidar Network (EARLINET) stations, J. Geophys. Res., 109, D18201, doi:10.1029/2004JD004638, 2004.

Menut, L., Flamant, C., Pelon, J., and Flamant, P. H.: Urban boundary-layer height determination from lidar measurements over the Paris area, Appl. Opt., 38, 6, 945-954, 1999.

Piketh, S. J., Annegarn, H. J., and Tyson, P. D.: Lower tropospheric aerosol loadings over South Africa: The relative contribution of aeolian dust, industrial emissions, and biomass burning, J. Geophys. Res., 104, 1597-1607, doi:10.1029/1998JD100014, 1999.

Piketh, S. J., Swap, R. J., Maenhaut, W., Annegarn, H. J., and Formenti, P.: Chemical evidence of long-range atmospheric transport over southern Africa, J. Geophys. Res., 107, 4817, doi:10.1029/2002JD002056, 2002.

Queface, A. J., Piketh, S. J., Eck, T. F., Tsay, S. C., and Mavume, A. F.: Climatology of aerosol optcal properties in Southern Africa, Atmos. Environ., 45, 2910-2921, 2011.

Raghunandan, A., Scott, G., Zunckel, M., and Carter, W.: TAPM verification in South Africa: modelling surface meteorology at Alexander Bay and Richards Bay, Report done on behalf CSIR Natural Resources and the Environment, Congella, 2008.
Seibert, P., Beyrich, F., Gryning, S.-E., Joffre, S., Rasmussen, A., and Tecier, P.: Review and intercomparison of operational methods for the determination of the mixing height, Atmos. Environ., 34, 1001-1027, 2000.

Seidel, D. J., Zhang, Y., Beljaars, A., Golaz, J.-C., Jacobson, A. R., and Medeiros, B.: Climatology of the planetary boundary layer over the continental United States and Europe, J. Geophys. Res., 117, D17106, doi:10.1029/2012JD018143, 2012.

Stull, R. B.: An introduction to boundary layer meteorology, Kluwer Academic Publishers, ISBN: 90-277-2768-6, 1988.

Stull, R. B.: Meteorology for Scientists and Engineers, Second Edition, Brooks\&Cole, ISBN: 0-534-37214-7, 2000.

Swap, R. J., Annegarn, H. J., Suttles, J. T., King, M. D., Platnick, S., Privette, J. L., and Scholes, R. J.: Africa burning: A thematic analysis of the Southern African Regional Science Initiative (SAFARI 2000), J. Geophys. Res., 108, 8465, doi:10.1029/2003JD003747, 2003.

Troen, I. B. and Mahrt, L.: A simple model of the Atmospheric Boundary Layer; sensitivity to surface evaporation. Bound.-Lay. Meteorol., 37, 129-148, 1986.

Tsaknakis, G., Papayannis, A., Kokkalis, P., Amiridis, V., Kambezidis, H. D., Mamouri, R. E., Georgoussis, G., and Avdikos, G.: Inter-comparison of lidar and ceilometer retrievals for aerosol and Planetary Boundary Layer profiling over Athens, Greece. Atmos. Meas. Tech., 4, 1261-1273, doi:10.5194/amt-4-1261-2011, 2011.

van Pul, W. A. J., Holtslag, A. A. M., and Swart, D. P. J.: A comparison of atmospheric boundary layer heights inferred routinely from lidar and radiosondes at noon, Bound.-Layer Meteorol., 68, 173-191, 1994.

Vaughan, M. A., Winker, D. M., and Powell, K. A.: CALIOP Algorithm Theoretical Basis Document Part 2: Feature Detection and Layer Properties Algorithms, available at: http://www-calipso. larc.nasa.gov/resources/pdfs/PC-SCI-202_Part2_rev1x01.pdf (last access: 28 June 2013), 2005.

Venter, A. D., Vakkari, V., Beukes, J. P., van Zyl, P. G., Laakso, H., Mabaso, D., Tiitta, P., Josipovic, M., Kulmala, M., Pienaar, J. J., and Laakso, L.: An air quality assessment in the industrialised western Bushveld Igneous Complex, South Africa, S. Afr. J. Sci., 108, 84-93, doi:10.4102/sajs.v108i9/10.1059, 2012.

Winker, D., Hostetler, C., and Hunt, W.: CALIOP: The CALIPSO Lidar, Proc. 22nd International Laser Radar Conference (ESASP 561), Matera, Italy, 941-944, Vol. 6409 (SPIE, Bellingham, WA 2006), 640902, 2004.

Winker, D., Vaughan, M., and Hunt, W., The CALIPSO mission and initial results from CALIOP, Proc. SPIE, 6409, doi:10.1117/12.698003, 2006.

Winker, D. M., Hunt, W. H., and McGill, M. J.: Initial performance assessment of CALIOP, Geophys. Res. Lett., 34, L19803, doi:10.1029/2007GL030135, 2007.

Zawar-Reza, P. and Sturman, A.: Application of airshed modelling to the implementation of the New Zealand National Environmental Standards for air quality, Atmos. Environ., 42, 8785-8794, 2008.

Ångström, A.: On the atmospheric transmission of Sun radiation and on dust in the air, Geograf. Ann., 11, 156-166, 1929. 